\title{
WATER RELATIONS AND YIELD OF SESAME IN RELATION TO RIDGE WIDTH AND IRRIGATION REGIME
}

\author{
Ashry, M.R.K; Abdou, S.M.M.; Youssef, K.M.R. and El-Akram, M.F.I. \\ Soils, water and environment Res. Inst., A.R.C., Giza, Egypt. \\ Corresponding author: dr_samehabdou2004@yahoo.com
}

\section{ABSTRACT}

The present investigation was conducted at Tameia agriculture research station Fayoum governorate, Egypt, during 2010 and 2011 seasons to study the combined effect of ridge width treatments i.e. $R_{1}$ : ridges of $60 \mathrm{~cm}, R_{2}$ : ridges of $80 \mathrm{~cm}$ and $R_{3}$ : ridges of $100 \mathrm{~cm}$ (beds planted from both sides) and irrigation regime treatments i.e. $\mathrm{I}_{1}$ : irrigation at $40 \%$ Available Soil Moisture Depletion(ASMD), I $2_{2}$ : irrigation at $60 \%$ (ASMD) and $\mathrm{I}_{3}$ : irrigation at $80 \%$ (ASMD) on yield components, yield and some water relations of sesame crop (Shandaweel $-3 \mathrm{cv}$.). The split-plot design in randomized complatc block, with four replications was applied, where ridge width treatments were allocated to the main plots and the split ones were occupied with irrigation regime treatments.

The main obtained results were as follows:-

Plant height, capsule number plant ${ }^{-1}$, seed weight plant $^{-1}$, 1000seed weight, seed yield $\left(\mathrm{t} \mathrm{ha}^{-1}\right)$ and seed oil content $(\%)$ were significantly affected by ridge width treatments and irrigation regime in both seasons.

The highest averages of yield components, seed yield, $\mathrm{R}_{1} \mathrm{I}_{1}(1.311$ and $1.252 \mathrm{t} \mathrm{ha}^{-1}$ ) and seed oil content (51.84 and 51.24\%) were detected from planting on ridges of $60 \mathrm{~cm}$ width and irrigation at $40 \%$ ASMD in the two successive seasons.

Seasonal evapotranspiration as a function of all treatments were 121.01 and $117.68 \mathrm{~cm} \mathrm{ha}^{-1}$ in 2010 and 2011 seasons, respectively. Planting on ridges of $60 \mathrm{~cm}$ width and irrigation at 40\% ASMD gave the highest seasonal $\mathrm{ET}_{\mathrm{C}}$ values, i.e. 132.57 and $129.30 \mathrm{~cm} \mathrm{ha}^{-1}$ in 2010 and 2011 seasons, respectively. However, the lowest ET $_{C}$ values, i.e. 110.22 and $107.48 \mathrm{~cm} \mathrm{ha}^{-1}$ were detected from planting on ridges of $100 \mathrm{~cm}$ width (beds) and irrigation at 80\% ASMD in the two successive seasons. The crop coefficient $\left(\mathrm{K}_{\mathrm{C}}\right)$ values for the treatments which gave the highest seed yield and $\mathrm{ET}_{\mathrm{C}}$ values $\left(\mathrm{R}_{1} \mathrm{I}_{1}\right)$ were 0.42 , $0.62,0.80$ and 0.57 for May, June, July and August months, respectively, (average of the two seasons).

The highest water use efficiency values, i.e. 0.261 and $0.253 \mathrm{~kg}$ seeds $\mathrm{m}^{3}$ water consumed were resulted from planting on ridges of 60 $\mathrm{cm}$ width and irrigation at 40\% ASMD, in 2010 and 2011 seasons, respectively. It could be concluded that planting sesame on wide ridges of $100 \mathrm{~cm}$ (beds) saved about $7.7 \%\left(423 \mathrm{~m}^{3} \mathrm{ha}^{-1}\right)$ in water evapotranspiration and gave acceptable yield.

Key words: Sesame yield, yield components, ridge width, irrigation regime, sesame crop-water relationships.

Fayoum J. Agric. Res. \& Dev., Vol. 26, No.2, July, 2012 


\section{INTRODUCTION}

Sesame (Sesamum indicum L.) is one of the most important oil crop in Egypt due to its high seed oil content $(47-52 \%)$. Sesame oil is an excellent edible with semi-dry properties. To reduce the gap between local oil production and consumption, improving the agronomic practices e.g. tillage, fertilization, irrigation management, sowing dates, cultivation practices and introducing high - yielding varieties are needed for increasing sesame seed production. Majumdar and Roy(1992), Olowe and Busari(1994), Gercek et al. (2004) and Rahnama and Bakhashandeh (2006) reported that there was no significant difference in yield between 30 and $40 \mathrm{~cm}$ row spacing. and highest yield was obtained from $30 \mathrm{~cm}$ row spacing $\left(1620 \mathrm{~kg} \mathrm{ha}^{-1}\right)$. That $50 \mathrm{~cm}$ row spacing led to a decrease in the yield, plant height, number of capsules per plant and oil content. Davut et al. (2007) revealed that increasing irrigation intervals from 12 to 24 days decreased yield components and seed yield (from $180.5 \mathrm{~kg} \mathrm{ha}^{-1}$ to $113.2 \mathrm{~kg} \mathrm{ha}^{-1}$ ).

Regarding the effect of irrigation regime, Ainer and Metwally (1987), El-Serogy, (1998), Attia et al. (1999), Ghallab et al. (2001) and El-Naim and Ahmed (2010), found that the sesame yield and its components were higher as irrigation events increased. Moreover, the highest values of water consumption and water use efficiency for sesame crop were reported when irrigation was practiced as $50 \%$ of the available soil moisture was depleted, compared with 70 and $90 \%$ ones.

The present trials aimea to assessing different irrigation regimes, based on soil monitoring technique, as interacted with ridge width treatments to find out the optimum interaction resulting in the sesame yield potential and improved water use efficiency as well.

\section{MATERIALS AND METHODS}

Two field experiments were carried out at Tameia agriculture research station, Fayoum governorate, Egypt during 2010 and 2011 seasons to study the effect of ridge width and irrigation regime treatments on seed yield, yield components, seed oil content percentage and some sesame crop -water relations. Three ridge width, i.e. $\mathrm{R}_{1}$ : ridges of $60 \mathrm{~cm}, \mathrm{R}_{2}$ : ridges of $80 \mathrm{~cm}$ and $\mathrm{R}_{3}$ : ridges of $100 \mathrm{~cm}$ (beds planted from both sides) were combined with irrigation regime treatments i.e. $\mathrm{I}_{1}$ : irrigation at $40 \%$ Available Soil Moisture Depletion (ASMD), $\mathrm{I}_{2}$ : irrigation at $60 \%(\mathrm{ASMD})$ and $\mathrm{I}_{3}$ : irrigation at $80 \%$ (ASMD). The split- plot design in Mondomized complete blocks with four replicates was used, where ridge width occupied the main plots and irrigation regime treatments allocated to the sub-plots. The sub-plot area was $21 \mathrm{~m}^{2}(6.0$ $\times 3.5 \mathrm{~m}$ ). Sesame seeds (shandaweel-3 cv) at the rate of $9.52 \mathrm{~kg} \mathrm{ha}^{-1}$. At the $1^{\text {st }}$ irrigation, the plants were thinned to be two plants/hill. Calcium super phosphate $\left(15.5 \mathrm{P}_{2} \mathrm{O}_{5}\right)$ at rate of $476 \mathrm{~kg} \mathrm{ha}^{-1}$ were added during seed bed preparation. Nitrogen fertilization $\left(71.4 \mathrm{~kg} \mathrm{~N} \mathrm{ha}^{-1}\right)$ was applied in two equal doses at the $1^{\text {st }}$ and $2^{\text {nd }}$ irrigations. The preceding crop in the two seasons was Egyptian clover. Planting was in May $2^{\text {nd }}$ in the two seasons. Harvesting was done on August $29^{\text {th }}$ for the first and the second seasons. Soil physical and chemical properties of the experimental site were determined according to Klute (1986) and Page $\boldsymbol{e t}$ al. (1982) and presented in Table 1. The monthly averages of weather factors for Fayoum governorate during the two growing seasons are shown in Table 2. Soil moisture constants of the experimental field

Fayoum J. Agric. Res. \& Dev., Vol. 26, No.2, July, 2012 
WATER RELATIONS AND YIELD OF SESAME IN RELATION... 167 (mean of the two seasons) are listed in Table 3. At harvesting time, the following data were collected from each sub-plot.

I. Yield and yield component:

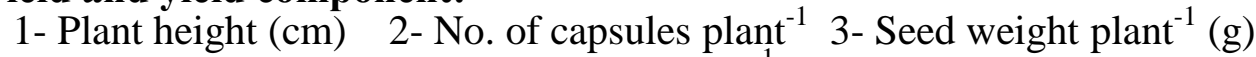

4- 1000-seed weight (g) 5- seed yield $\left(\mathrm{t} \mathrm{ha}^{-1}\right) \quad$ 6- seed oil content $(\%)$.

All the measurements and data collected were subjected to the statistical analysis as described by Snedecor and Cochran (1980).

Table 1: Physical and chemical properties of the experimental field during 2010 and 2011 seasons (average of two seasons)

\begin{tabular}{|c|c|c|c|c|c|c|c|c|c|c|}
\hline \multicolumn{2}{|c|}{ Sand\% } & \multicolumn{2}{|c|}{ Silt \% } & \multicolumn{2}{|c|}{ Clay\% } & \multicolumn{3}{|c|}{ Texture classes } & \multicolumn{2}{|c|}{ Organic matter\% } \\
\hline \multicolumn{2}{|c|}{23.43} & \multicolumn{2}{|c|}{44.37} & \multicolumn{2}{|c|}{32.20} & \multicolumn{3}{|c|}{ Clay loam } & \multicolumn{2}{|c|}{1.64} \\
\hline \multicolumn{4}{|c|}{ Soluble cations, meq/L } & \multicolumn{4}{|c|}{ Soluble anions, meq/L } & $\begin{array}{c}\text { EC } \\
\mathrm{dS} / \mathrm{m}\end{array}$ & $\begin{array}{c}1: 2.5 \\
\text { Extract } \\
\text { pH }\end{array}$ & $\begin{array}{c}\text { CEC } \\
\text { Meq/100 } \\
\text { gm soil }\end{array}$ \\
\hline $\mathbf{C a}^{++}$ & $\mathbf{M g}^{+}$ & $\mathrm{Na}^{+}$ & $\mathbf{K}^{+}$ & $\mathrm{Cl}^{-}$ & $\mathrm{HCO}_{3}^{-}$ & $\mathrm{CO}_{3}^{-}$ & $\mathrm{SO}_{4}^{--}$ & & & \\
\hline 16.91 & 10.94 & 45.96 & $\mathbf{0 . 3 5}$ & 38.56 & 2.41 & - & 33.15 & 7.52 & 8.12 & 43.17 \\
\hline
\end{tabular}

Table 2: The monthly averages of weather factors for Fayoum Governorate during 2010 and 2011 seasons

\begin{tabular}{|c|c|c|c|c|c|c|c|}
\hline \multirow[b]{2}{*}{ Month } & \multirow[b]{2}{*}{ Season } & \multicolumn{3}{|c|}{ Temperature C } & \multirow{2}{*}{$\begin{array}{c}\text { Relative } \\
\text { humidity } \\
(\%)\end{array}$} & \multirow{2}{*}{$\begin{array}{l}\text { Wind speed } \\
(\mathrm{m} / \mathrm{sec})\end{array}$} & \multirow{2}{*}{$\begin{array}{c}\text { Pan } \\
\text { evaporation } \\
(\mathrm{mm} / \mathrm{day})\end{array}$} \\
\hline & & Max. & Min. & Mean & & & \\
\hline \multirow[t]{2}{*}{ May } & 2010 & 33.6 & 17.8 & 25.7 & 44 & 2.78 & 6.7 \\
\hline & 2011 & 32.8 & $\mathbf{1 7 . 4}$ & 25.1 & 44 & 2.77 & 6.5 \\
\hline \multirow[t]{2}{*}{ June } & 2010 & 38.4 & 21.4 & 29.9 & 48 & 3.01 & 8.3 \\
\hline & 2011 & 35.7 & 20.6 & 28.2 & 48 & 2.98 & 8.1 \\
\hline \multirow[t]{2}{*}{ July } & 2010 & 36.3 & 22.4 & 29.3 & 50 & 2.58 & 7.8 \\
\hline & 2011 & 38.7 & 22.5 & 30.6 & 50 & 2.57 & 7.6 \\
\hline \multirow[t]{2}{*}{ August } & 2010 & 40.2 & 24.5 & 32.3 & 46 & 2.44 & 7.4 \\
\hline & 2011 & 38.6 & 22.9 & 30.8 & 49 & 2.42 & 7.2 \\
\hline
\end{tabular}

Table 3: The average values of soil moisture constants for the experimental field during 2010 and 2011 seasons (average of the two seasons)

\begin{tabular}{|c|c|c|c|c|}
\hline Soil depth(cm) & $\begin{array}{c}\text { Field } \\
\text { capacity } \\
(\%)\end{array}$ & $\begin{array}{c}\text { Wilting } \\
\text { point } \\
(\%)\end{array}$ & $\begin{array}{c}\text { Bulk } \\
\text { density } \\
\left(\mathbf{g ~ c m}^{-3}\right)\end{array}$ & $\begin{array}{c}\text { Available } \\
\text { Moisture } \\
(\%)\end{array}$ \\
\hline $00-15$ & 37.94 & 18.71 & 1.31 & 19.23 \\
\hline $15-30$ & 35.65 & 16.55 & 1.49 & 19.10 \\
\hline $30-45$ & 34.24 & 16.02 & 1.40 & 18.22 \\
\hline $45-60$ & 29.71 & 14.32 & 1.25 & 15.39 \\
\hline
\end{tabular}

II. Crop- water relations:

1. Seasonal evapotranspiration $\left(\mathbf{E T _ { C }}\right)$

On determination the crop water consumptive use $\left(\mathrm{ET}_{\mathrm{C}}\right)$, the soil samples were taken just before and 48 hours after each irrigation, as well as at harvest time, in $15 \mathrm{~cm}$ increment system to $60 \mathrm{~cm}$ of soil profile. The crop water

Fayoum J. Agric. Res. \& Dev., Vol. 26, No.2, July, 2012 
consumptive use between each two successive irrigations was calculated according to Israelsen and Hansen, 1962 as follows :-

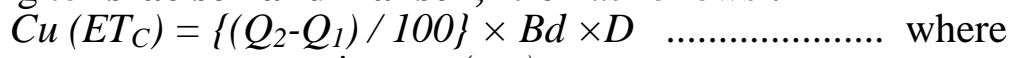

$\mathrm{Cu}=$ crop water consumptive use $(\mathrm{cm})$.

$Q_{2}=$ soil moisture percentage (wt/wt) 48 hours after irrigation.

$Q_{1}=$ soil moisture percentage(wt/wt) just before irrigation.

$B d=$ soil bulk density $\left(\mathrm{gmcm}^{-3}\right)$.

$D=$ soil layer depth $(\mathrm{cm})$.

2. Daily $\mathbf{E T}_{\mathrm{C}}$ rate $(\mathrm{mm} / \mathrm{day})$.

It was calculated from the $\mathrm{ET}_{\mathrm{C}}$ between each two successive irrigations divided by the number of days.

\section{Reference evapotranspiration $\left(\mathbf{E T}_{\mathbf{0}}\right)$}

It was estimated as $\left(\mathrm{mm} \mathrm{day}^{-1}\right)$, using the monthly averages of weather factors of Fayoum Governorate according to FAO-Penman Monteith equation (Allen et al. 1998).

4. Crop Coefficient $\left(K_{C}\right)$.

The crop coefficient was calculated as follows:

$\mathrm{K}_{\mathrm{C}}=\mathrm{ET}_{\mathrm{C}} / \mathrm{ET}_{0}$

$\mathrm{ET}_{\mathrm{C}}=$ Actual crop evapotranspiration $\left(\mathrm{mm} \mathrm{day}^{-1}\right)$

$\mathrm{ET}_{0}=$ Reference evapotranspiration $\left(\mathrm{mm} \mathrm{day}^{-1}\right)$.

\section{Water Use Efficiency (WUE)}

The water use efficiency as $\mathrm{kg} \mathrm{seedm}^{-3}$ water consumed was calculated for different treatments as described by Vites (1965):

WUE, $\mathrm{kg} \mathrm{m}^{-3}=\left\{\right.$ seed yield $\left(\mathrm{kg} \mathrm{ha}^{-1}\right) /$ Seasonal crop evapotranspiration $\left(\mathrm{m}^{3} \mathrm{ha}^{-1}\right)$.

\section{RESULTS AND DISCUSSION \\ Yield and yield components:}

Data in Table (4) indicate that planting on $60 \mathrm{~cm}$ ridge width gave the highest averages of sesame seed yield and its components in 2010 and 2011 seasons. Planting sesame on $80 \mathrm{~cm}$ ridge width significantly reduced plant height, capsules number plant ${ }^{-1}, 1000$-seed weight, seed yield $\mathrm{ha}^{-1}$ and seed oil percentage by $3.90,10.35,11.13,3.99,13.73$ and $3.18 \%$, respectively, in 2010 and by $4.55,8.45,8.11,2.62,13.42$ and $2.28 \%$, in 2011 season, respectively. The lowest averages of seed yield and its components were detected from planting on $100 \mathrm{~cm}$ wide ridge width (beds). These results may be referred to the inadequate wetting of the lower parts under wide ridges (beds) for some days after irrigation; which in turn reduced growth of roots. These results are consistent with those found by Majumdar and Roy (1992), Olowe and Busari (1994), Gercek \& Simsek (2004) and Rahnama and Bakhashandeh (2006).

Regarding the effect of irrigation regime treatments, data in Table (4) show that sesame yield and its components were significantly affected by treatments in both seasons. Irrigation sesame at 40\% ASMD gave the highest averages of yield and its components, whereas, irrigation at $80 \%$ ASMD gave the lowest ones in both seasons. Increasing the available soil moisture depletion (ASMD) from 40 to $80 \%$ significantly decrease plant height, capsules number plant ${ }^{-1}, 1000$-seed weight, seed yield ha ${ }^{-1}$ and seed oil content percentage in the first season by $8.63,29.85,11.45,10.14,24.77$ and $6.13 \%$, respectively, and by $7.70,33.50,16.23,8.93,23.05$ and $6.12 \%$, respectively, in the second season. These results may be referred to the effect of moisture

Fayoum J. Agric. Res. \& Dev., Vol. 26, No.2, July, 2012 
WATER RELATIONS AND YIELD OF SESAME IN RELATION... 169

Table 4

Fayoum J. Agric. Res. \& Dev., Vol. 26, No.2, July, 2012 
stress (under $80 \%$ ASMD treatment) on reducing photosynthesis, cell division, stem elongation, leaf area, leaf duration and dry matter accumulation in plant organs. The obtained results are in the same line with those reported by Davut et al. (2007).

Data in Table (4) indicate that the seed yield and its components were significantly affected by the interaction between ridge width and irrigation regime treatments in the both seasons except plant height and 1000-seed weight. The highest averages of capsules number plant ${ }^{-1}$, seed yield ha $^{-1}$ and seed oil content percentage were detected from planting on $60 \mathrm{~cm}$ ridge width and irrigation at $40 \%$ ASMD in both seasons. On the other hand, the lowest averages of yield and its components were resulted from planting sesame on $100 \mathrm{~cm}$ wide ridges (beds) as interacted with irrigation at 80\% ASMD in both seasons of study.

\section{Crop water relations:}

Seasonal evapotranspiration $\left(\mathbf{E T}_{\mathbf{C}}\right)$

Results in Table (5) indicate that seasonal evapotranspiration $\left(\mathrm{ET}_{\mathrm{C}}\right)$ of sesame crop, as a function of ridge width and irrigation regime treatments and their interaction were, 121.01 and $117.68 \mathrm{~cm} \mathrm{ha}^{-9}$ in 2010 and 2011 seasons, respectively.

Planting on $60 \mathrm{~cm}$ ridge width gave the highest values of sesame ET, i.e. 125.19 and $122.24 \mathrm{~cm}$ in the two successive seasons. Planting sesame on $80 \mathrm{~cm}$ or $100 \mathrm{~cm}$ (beds) decreased seasonal $\mathrm{ET}_{\mathrm{C}}$ in 2010 season by 3.06 and $6.94 \%$ and by 3.58 and $7.57 \%$ in 2011 season, respectively, compared with planting on $60 \mathrm{~cm}$ ridge width. The present results may be referred to that the bottoms between wide ridges (beds) will be half those between normal ridges $(60 \mathrm{~cm}$ width) and this in turn reduced water runoff, evaporation and inadequate wetting of the lower parts of the field, which may also reduced plant transpiration.

Regarding the effect of irrigation regime treatments, data in Table (5) show that irrigating sesame at $40 \%$ ASMD produced the highest values of ET $_{C}$ which reached 127.47 and $123.90 \mathrm{~cm}$ in 2010 and 2011 seasons, respectively. The lowest $\mathrm{ET}_{\mathrm{C}}$ values i.e. 115.02 and $111.84 \mathrm{~cm}$ were resulted from irrigating at $80 \%$ ASMD in two successive seasons. Moreover, irrigation at $60 \%$ ASMD decreased $\mathrm{ET}_{\mathrm{C}}$ by 5.43 and $5.30 \%$ in 2010 and 2011 seasons, respectively, comparable with that irrigated at $40 \%$ ASMD This could be attributed to increasing the available soil moisture in the root zone of sesame plants under irrigation at $40 \%$ ASMD treatment, where the crop received more irrigation events, resulted in higher $\mathrm{ET}_{\mathrm{C}}$ values. Higher both transpiration rate from plants canopy and evaporative demands from soil surface under higher available soil moisture are responsible for higher $\mathrm{ET}_{\mathrm{C}}$ values. Under water stress i.e. irrigating at 60 or $80 \%$ ASMD, the transpiration from plants may was decreased as a result of poor vegetative growth and less evaporation from dry soil surface as well. These results are in accordance with those reported by Ainer and Metwally (1987), El-Serogy, (1998), Attia et al. (1999), Ghallab et al. (2001) and El-Naim and Ahmed (2010).

Data in Table (5) indicate that planting on $60 \mathrm{~cm}$ ridge width as interacted with irrigating at $40 \%$ ASMD, gave the highest values of $\mathrm{ET}_{\mathrm{C}}$ which comprised 132.57 and $129.31 \mathrm{~cm}$ in 2010 and 2011 seasons, respectively. However, the lowest $\mathrm{ET}_{\mathrm{C}}$ values, i.e. 110.22 and $111.84 \mathrm{~cm}$ in the two

Fayoum J. Agric. Res. \& Dev., Vol. 26, No.2, July, 2012 
WATER RELATIONS AND YIELD OF SESAME IN RELATION... 171 successive seasons were obtained from the interaction between planting on $100 \mathrm{~cm}$ wide ridge width (beds) and irrigation at $80 \%$ ASMD

Table 5: Averages of seasonal evapotranspiration $\left(E_{C}, \mathrm{~cm}\right)$ in $\mathrm{cm} \mathrm{ha}^{-1}$ of sesame crop as affected by ridge width, irrigation regime and their interaction in 2010 and 2011 seasons

\begin{tabular}{|c|c|c|c|c|c|c|c|c|}
\hline \multirow{3}{*}{ Ridge width $\begin{array}{r}\text { Irrigation } \\
\text { regime }\end{array}$} & \multirow{2}{*}{\multicolumn{3}{|c|}{$\begin{array}{l}2010 \text { season } \\
\begin{array}{l}\text { rrigation regime } \\
\text { (ASMD) }\end{array}\end{array}$}} & \multirow{3}{*}{ Mean } & & 11 seas & & \multirow{3}{*}{ Mean } \\
\hline & & & & & \multicolumn{3}{|c|}{$\begin{array}{c}\text { Irrigation regime } \\
\text { (ASMD) }\end{array}$} & \\
\hline & $40 \%$ & $60 \%$ & $80 \%$ & & $40 \%$ & $60 \%$ & $80 \%$ & \\
\hline $\mathbf{R}_{1}$ & 132.57 & 124.04 & 118.95 & 125.18 & 129.30 & 122.24 & 115.17 & 122.24 \\
\hline $\mathbf{R}_{2}$ & 127.14 & 121.02 & 115.93 & 121.36 & 123.36 & 117.33 & 112.86 & 117.85 \\
\hline $\mathbf{R}_{\mathbf{3}}$ & 122.69 & 116.60 & 110.22 & 116.50 & 119.02 & 112.40 & 107.48 & 112.97 \\
\hline Mean & 127.47 & 120.55 & 115.03 & 121.01 & 123.89 & 117.32 & 111.84 & 117.68 \\
\hline
\end{tabular}

$* R$ !, $R_{2} a n d R_{3}$ are referred to $60 \mathrm{~cm}, 80 \mathrm{~cm}$ and $100 \mathrm{~cm}$ (beds) ridge widths, respectively

\section{Daily $\operatorname{ET}_{\mathrm{C}}\left(\mathbf{m m ~ d a y}^{-\mathbf{1}}\right)$}

Results in Table (6) show that the daily $\mathrm{ET}_{\mathrm{C}}$ rates, as influenced by different treatments tested in both seasons, started with low values during May and then increased again during June to reach its maximum values on July. Thereafter, it tended to decrease August (plant harvesting). These results are referred to that at the initial growth stage, most of the water loss is due to evaporation from the bare soil and lower evaporation demands (lower values of temperature and solar radiation). Thereafter, as the plant cover and temperature increased both evaporation and transpiration tended to increase and reached maximum values during July. At maturity stage $\mathrm{ET}_{\mathrm{C}}$ rate decreased again during August (harvesting). The results in Table (7) indicate that the highest values of $\mathrm{ET}_{\mathrm{C}}$, during the two growing seasons, were reported during (May-August) under planting on $60 \mathrm{~cm}$ ridge width treatments. On the other hand, under planting on $100 \mathrm{~cm}$ ridge width (beds) the lowest values of daily $\mathrm{ET}_{\mathrm{C}}$ rates during growing seasons were recorded and such tend was observed in 2010 and 2011 seasons.

Data in Table (6) show that the daily $\mathrm{ET}_{\mathrm{C}}$ rates of sesame during the growing season months (May - August) of both seasons, were increased by irrigation at $40 \%$ ASMD and the same trend was observed either with irrigation at $60 \%$ or $80 \%$ ASMD. It is obvious that increasing the available moisture in sesame root zone (frequent irrigation i.e. more irrigation events) resulted in increasing the $\mathrm{ET}_{\mathrm{C}}$ rate during the entire growing season. These results are in the same line of those reported by Ainer and Metwally (1987), El-Serogy. (1998), Attia et al. (1999), Ghallab et al. (2001) and El-Naim and Ahmed (2010).

\section{Reference evapotranspiration $\left(\mathbf{E T}_{0}\right)$}

Reference evapotranspiration rate $\left(\mathrm{ET}_{0}\right)$ in $\mathrm{mmday}^{-1}$ during the months of sesame growing season of 2010 and 2011, were estimated using the FAO penman-Monteith method via the meteorological data of Fayoum governorate (Table 6). Data indicate that the $\mathrm{ET}_{0}$ rate values were somewhat low during May, and then increased during June and August in both seasons. These results are attributed to the variation in weather factors from one month to

Fayoum J. Agric. Res. \& Dev., Vol. 26, No.2, July, 2012 
another. Allen et al. (1998) reported that the reference ET values depend mainly on the evaporative power of the air at each area, i.e. temperature, radiation, relative humidity and wind speed.

Table (6): Effect of ridge width, irrigation regime treatments and their interaction on daily water consumption use ( $\mathrm{mm} / \mathrm{day})$ in 2010 and 2011 seasons.

\begin{tabular}{|c|c|c|c|c|c|c|c|c|c|}
\hline \multicolumn{2}{|r|}{ Treatment } & \multirow{2}{*}{\multicolumn{4}{|c|}{2010}} & \multirow{2}{*}{\multicolumn{4}{|c|}{2011}} \\
\hline \multirow{2}{*}{$\begin{array}{l}\text { Ridge } \\
\text { width }\end{array}$} & \multirow{2}{*}{$\begin{array}{c}\text { Irrigation } \\
\text { Regime(ASMD) }\end{array}$} & & & & & & & & \\
\hline & & May & Jun & July & Aug & May & Jun & July & Aug. \\
\hline \multirow{4}{*}{$\mathbf{R}_{1}$} & $40 \%$ & 2.65 & 5.40 & 6.24 & 4.22 & 2.94 & 4.85 & 6.16 & 4.09 \\
\hline & $60 \%$ & 2.65 & 5.15 & 6.01 & 3.92 & 2.94 & 4.47 & 5.85 & 3.80 \\
\hline & $80 \%$ & 2.65 & 4.48 & 5.69 & 3.77 & 2.94 & 4.08 & 5.54 & 3.50 \\
\hline & Mean & 2.65 & 5.01 & 5.98 & 3.97 & 2.94 & 4.47 & 5.85 & 3.80 \\
\hline \multirow{4}{*}{$\mathbf{R}_{2}$} & $40 \%$ & 2.52 & 5.15 & 6.01 & 4.07 & 2.87 & 4.62 & 5.85 & 3.87 \\
\hline & $60 \%$ & 2.52 & 4.98 & 5.62 & 3.77 & 2.87 & 4.31 & 5.54 & 3.65 \\
\hline & $80 \%$ & 2.52 & 4.73 & 5.30 & 3.63 & 2.87 & 4.16 & 5.15 & 3.58 \\
\hline & Mean & 2.52 & 4.95 & 5.64 & 3.82 & 2.87 & 4.36 & 5.51 & 3.70 \\
\hline \multirow{4}{*}{$\mathbf{R}_{3}$} & $40 \%$ & 2.52 & 4.90 & 5.85 & 3.85 & 2.87 & 4.39 & 5.69 & 3.65 \\
\hline & $60 \%$ & 2.52 & 4.81 & 5.38 & 3.55 & 2.87 & 4.16 & 5.23 & 3.43 \\
\hline & $80 \%$ & 2.52 & 4.32 & 5.07 & 3.48 & 2.87 & 3.85 & 4.99 & 3.29 \\
\hline & Mean & 2.52 & 4.68 & 5.43 & 3.63 & 2.87 & 4.13 & 5.30 & 3.46 \\
\hline \multicolumn{2}{|c|}{ Mean of irrigation $40 \%$} & 2.56 & 5.15 & 6.03 & 4.05 & 2.89 & 4.62 & 5.90 & 3.87 \\
\hline \multicolumn{2}{|c|}{$60 \%$} & 2.56 & 4.98 & 5.67 & 3.75 & 2.89 & 4.31 & 5.54 & 3.63 \\
\hline \multicolumn{2}{|c|}{$80 \%$} & 2.56 & 4.67 & 5.35 & 3.62 & 2.89 & 4.03 & 5.23 & 3.46 \\
\hline \multicolumn{2}{|c|}{ Over mean } & 2.56 & 4.89 & 5.68 & 3.81 & 2.89 & 4.32 & 5.56 & 3.65 \\
\hline
\end{tabular}

$* R$ !, $R_{2} a n d R_{3}$ are referred to $60 \mathrm{~cm}, 80 \mathrm{~cm}$ and $100 \mathrm{~cm}$ (beds) ridge widths, respectively

\section{Crop coefficient $\left(\mathbf{K}_{\mathbf{C}}\right)$}

The crop coefficient $\left(\mathrm{K}_{\mathrm{C}}\right)$ is a function of both Etc and $\mathrm{ET}_{0}$ values. The crop cover percentage affects ETc and consequently Kc values, Table 6 . Results in Table (7) show that the over all mean $\mathrm{K}_{\mathrm{C}}$ value of the adopted treatments, started with lower values $(0.41$ and 0.41$)$, after planting, during May and then increased during Jun (0.58 and 0.56) The $\mathrm{K}_{\mathrm{C}}$ values reached its maximum values ( 0.73 and 0.71$)$ as the percentage of crop cover increased during July and then tended to decrease again (0.52 and 0.50) during August (at harvesting).

Data in Table (7) reveal that planting on $60 \mathrm{~cm}$ ridge width, comparable with planting on 80 or $100 \mathrm{~cm}$ ridge width exhibited the highest $\mathrm{K}_{\mathrm{C}}$ values during the entire growing season. Increasing the irrigation events (irrigating at $40 \%$ ASMD) seemed to increase the $\mathrm{K}_{\mathrm{C}}$ values entire the growing season, whereas the lowest $\mathrm{K}_{\mathrm{C}}$ values were observed under irrigation at $80 \%$ ASMD and such findings were true in both seasons. The $\mathrm{K}_{\mathrm{C}}$ values of sesame, as a function of different treatments were 0.41, 0.57, 0.72, and 0.51 for May, June, July and August, respectively, (average of the two seasons). Such findings are in the same line of those reported by Ainer and Metwally (1987), El-Serogy. (1998), Attia et al. (1999), Ghallab et al. (2001) and El-Naim and Ahmed (2010). 
WATER RELATIONS AND YIELD OF SESAME IN RELATION... 173

Table (7): Reference evapotranspiration, $\mathbf{E T}_{0}$ (mm/day) and $K_{C}$ for seasame crop during 2010 and 2011 seasons as affected by ridge width and irrigation regime treatments.

\begin{tabular}{|c|c|c|c|c|c|c|c|c|c|}
\hline \multicolumn{2}{|c|}{ Treatments } & \multicolumn{4}{|c|}{2010} & \multicolumn{4}{|c|}{2011} \\
\hline Ridge width & $\begin{array}{l}\text { Irrigation } \\
\text { Regime } \\
\text { (ASMD) }\end{array}$ & May & Jun & July & Aug. & May & Jun & July & Aug. \\
\hline \multicolumn{2}{|c|}{ Reference $\mathrm{ET}_{0} \mathrm{~mm} /$ day } & 6.3 & 8.3 & 7.8 & 7.4 & 7.00 & 7.70 & 7.80 & 7.30 \\
\hline \multirow{4}{*}{$\mathbf{R}_{1}$} & $40 \%$ & 0.42 & 0.65 & 0.80 & 0.57 & 0.42 & 0.63 & 0.79 & 0.56 \\
\hline & $60 \%$ & 0.42 & 0.62 & 0.77 & 0.53 & 0.42 & 0.58 & 0.75 & 0.52 \\
\hline & $80 \%$ & 0.42 & 0.57 & 0.73 & 0.51 & 0.42 & 0.53 & 0.71 & 0.49 \\
\hline & Mean & 0.42 & 0.61 & 0.77 & 0.54 & 0.42 & 0.58 & 0.75 & 0.52 \\
\hline \multirow{4}{*}{$\mathbf{R}_{2}$} & $40 \%$ & 0.40 & 0.62 & 0.77 & 0.55 & 0.41 & 0.60 & 0.75 & 0.53 \\
\hline & $60 \%$ & 0.40 & 0.60 & 0.72 & 0.51 & 0.41 & 0.56 & 0.71 & 0.50 \\
\hline & $80 \%$ & 0.40 & 0.54 & 0.68 & 0.49 & 0.41 & 0.52 & 0.66 & 0.47 \\
\hline & Mean & 0.40 & 0.59 & 0.72 & 0.52 & 0.41 & 0.56 & 0.71 & 0.50 \\
\hline \multirow{4}{*}{$\mathbf{R}_{3}$} & $40 \%$ & 0.40 & 0.59 & 0.75 & 0.52 & 0.41 & 0.57 & 0.73 & 0.50 \\
\hline & $60 \%$ & 0.40 & 0.58 & 0.69 & 0.48 & 0.41 & 0.54 & 0.67 & 0.47 \\
\hline & $80 \%$ & 0.40 & 0.52 & 0.65 & 0.47 & 0.41 & 0.50 & 0.64 & 0.45 \\
\hline & Mean & 0.40 & 0.56 & 0.70 & 0.49 & 0.41 & 0.54 & 0.68 & 0.47 \\
\hline \multicolumn{2}{|c|}{ Mean of irrigation } & & & & & & & & \\
\hline \multicolumn{2}{|c|}{$40 \%$} & 0.41 & 0.62 & 0.77 & 0.55 & 0.41 & 0.60 & 0.76 & 0.53 \\
\hline \multicolumn{2}{|c|}{$60 \%$} & 0.41 & 0.60 & 0.73 & 0.51 & 0.41 & 0.56 & 0.71 & 0.50 \\
\hline \multicolumn{2}{|c|}{$80 \%$} & 0.41 & 0.54 & 0.69 & 0.49 & 0.41 & 0.52 & 0.67 & 0.47 \\
\hline \multicolumn{2}{|c|}{ Over all mean } & 0.41 & 0.59 & 0.73 & 0.52 & 0.41 & 0.56 & 0.71 & 0.50 \\
\hline
\end{tabular}

$* R$ !, $R_{2}$ and $R_{3}$ are referred to $60 \mathrm{~cm}, 80 \mathrm{~cm}$ and $100 \mathrm{~cm}$ (beds) ridge widths, respectively

Water Use Efficiency (WUE)

Results in Table (8) show that WUE average values, as affected by ridge width and irrigation regime treatments were 0.221 and $0.216 \mathrm{~kg}$ seeds $/ \mathrm{m}^{3}$ water consumed in 2010 and 2011 seasons, respectively. The highest water use efficiency values of 0.249 and $0.241 \mathrm{~kg}$ seeds $\mathrm{m}^{-3}$ water consumed in 2010 and 2011 seasons, respectively, were obtained from planting on $60 \mathrm{~cm}$ ridge width, whereas, the lowest values, i.e. 0.194 and $0.189 \mathrm{~kg}$ seeds $\mathrm{m}^{-3}$ water consumed in the two successive seasons were obtained from planting on $100 \mathrm{~cm}$ ridge width (beds).

Regardless irrigation regime treatments, data in Table (8) reveal that the highest WUE values, i.e. 0.237 and $0.233 \mathrm{~kg}$ seeds $\mathrm{m}^{-3}$ water consumed in 2010 and 2011 seasons, respectively, were detected from irrigating sesame plants at $40 \%$ ASMD. Irrigation at $80 \%$ ASMD gave the lowest WUE values, i.e. 0.203 and $0.198 \mathrm{~kg}$ seeds $\mathrm{m}^{-3}$ water consumed in the two successive seasons, respectively. These results are in agreement with those reported by Ainer and Metwally (1987), El-Serogy, (1998), Attia et al. (1999), Ghallab et al. (2001) and El-Naim and Ahmed (2010). 
Ashry, M.R.K; et al.

Table 8: Water use efficiency for sesame crop as affected by ridge width and irrigation regime treatments in 2010 and 2011 seasons

\begin{tabular}{|c|c|c|c|c|c|c|c|c|}
\hline \multirow{3}{*}{$\begin{array}{l}\text { Ridge } \\
\text { width }\end{array}$} & \multicolumn{4}{|c|}{2010 season } & \multicolumn{4}{|c|}{2011 season } \\
\hline & \multicolumn{4}{|c|}{ Irrigation regime (ASMD) } & \multicolumn{4}{|c|}{ Irrigation regime (ASMD) } \\
\hline & $40 \%$ & $60 \%$ & $80 \%$ & Mean & $40 \%$ & $60 \%$ & $80 \%$ & Mean \\
\hline $\mathbf{R}_{1}$ & 0.261 & 0.256 & 0.229 & 0.249 & 0.253 & 0.246 & 0.225 & 0.241 \\
\hline $\mathbf{R}_{2}$ & 0.236 & 0.225 & 0.203 & 0.221 & 0.232 & 0.225 & 0.199 & 0.219 \\
\hline $\mathbf{R}_{\mathbf{3}}$ & 0.215 & 0.190 & 0.176 & 0.194 & 0.213 & 0.183 & 0.171 & 0.189 \\
\hline Mean & $\mathbf{0 . 2 3 7}$ & 0.224 & 0.203 & 0.221 & 0.233 & 0.218 & 0.198 & 0.216 \\
\hline
\end{tabular}

$* R$ !, $R_{2}$ and $R_{3}$ are referred to $60 \mathrm{~cm}, 80 \mathrm{~cm}$ and $100 \mathrm{~cm}$ (beds) ridge widths, respectively

Under the present experiment conditions and on managing the limited irrigation water efficiently, it is advisable to plant sesame on ridge width 100 (beds) $\mathrm{cm}$ and irrigate it at 40\% ASMD to obtain reasonable figure for water use efficiency and to save irrigation water as about $7.7 \%$.

\section{REFERENCES}

Ainer, N.G. and Metwally, M.A. (1987). Effect of antitranspirants on seed yield and water relations of sesame crop. Ann. of Agric. Sci., Moshtohor 25(1): 79-85.

Allen, R.G.; Pereio; L.S.; Raes, D.S. and Smith, M.D. (1998). Crop evapotranspiration. Guidelines for computing crop water requirements. Irrigation and Drainage, PP No.56.FAO, Rome, Italy.

Attia, M.M.; A.M. Osman; Sayed M.A. and El-Kafoury, A.A. (1999). Effect of irrigation intervals and row width on yield, water use efficiency and some economic studies on sesame in calcareous soil. Third conference of on-farm irrigation and agroclimatology. Vol. 1(No. 2): 525-533.

Davut Karaaslan, Erkan Boydak, Sinan Gercek and Mehmet Simsek (2007). Influence of irrigation intervals and row spacing on some yield components of sesame grown in Harran Region. Asian J. of plant Sci. 6(4): 623-627.

El-Naim, M.A. and Ahmed M.F. (2010). Effect of irrigation on consumptive use, water use efficiency and crop coefficient of sesame J. Agric. Extension and Rural Dev., Vol. 2 (4): 59-63.

El-Serogy, S.T.M.A. (1998). Agricultural studies on growth yield and yield components of sesame. Ph.D. Thesis, Agron., Fac. Agric., Minia Univ., Egypt.

Gercek, S.E.B. and Simsek, M. (2004). Effect of irrigation methods and row spacing on yield and yield components of sesame (sesamum indicum L.). Pakistan J. of Bio. Sci. 7 (12): 2149-2154.

Ghallab, K.H.; Yousef, K.M.R. and Megawer, Ekram A. (2001). Yield and water relations of some promising sesam lines grown in new reclaimed soils. Ann. Agric. Sci., Moshtohor 39(4): 1977-1992.

Israelsen, O.W. and Hansen, V.E. (1962). Irrigation Principles and Practices. The $3^{\text {rd }}$ ed. John, Wiley and Sons Inc., New York.

Klute, A. (1986). Methods of Soil Analysis. Part-1: Physical and Mineralogical Methods $\left(2^{\text {nd }}\right.$ ed.) American Society of Agronomy, Madison, Wisconsin. U.S.A.

Majumdar, D.K. and Roy, S.K. (1992). Response of summer sesame (sesamum indicum L.) to irrigation, row spacing and plant population. Ind. J. Agron. 37: 758-762.

Fayoum J. Agric. Res. \& Dev., Vol. 26, No.2, July, 2012 
WATER RELATIONS AND YIELD OF SESAME IN RELATION... 175

Olowe, V.I.O. and Busari, L.D. (1994). Appropriate plant population and spacing for sesame (sesamum indicum L.) in the southern guinea Savanna of Nigeria. Tropical oilseeds J. 2:18-27.

Page, A.L.; R.H. Miller and D.R. Keeney (eds.) (1982). Methods of Soil Analysis. Part-2: Chemical and Microbiological Properties. ( $2^{\text {nd }}$ ed.) American Society of Agronomy, Madison, Wisconsin. USA.

Rahnama, A. and Bakhashandeh, A. (2006). Determination of optimum row-spacing and plant density for Uni- branched sesame in Khuzestan province. J. Agric. Sci. Technol. 8: 25-33.

Snedecor, G.W. and W.G. Cochran (1980). Statistical Methods. ( $7^{\text {th }}$ ed.) Iowa State Univ. Iowa, U.S.A.

Vites, F.G. (1965). Increasing water use efficiency by soil management in plant environment and efficient water use. J. American Soc. Agron. 26: 537-546.

العلاقات المائية والمحصول في السمسم وعلاقته بعرض الذط ونقص الرطوبة الارضية

محمد رجب كامل عشري، سامح محمود محمد عبده، كمال ميلاد يوسف ومحمد الاكرم فتحي إبراهيم

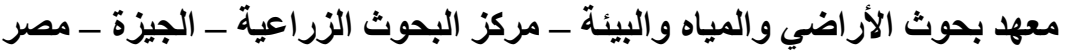

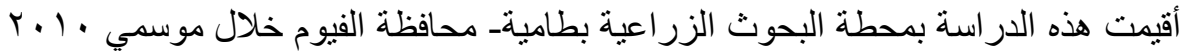

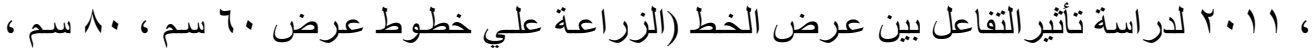

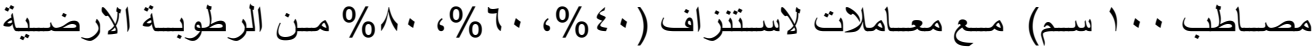

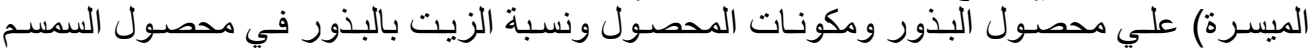

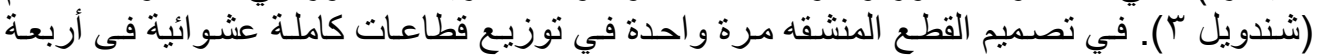

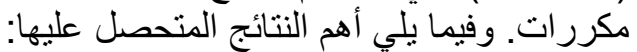

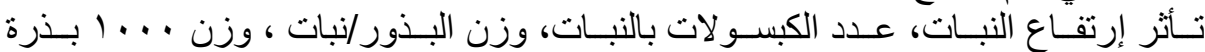

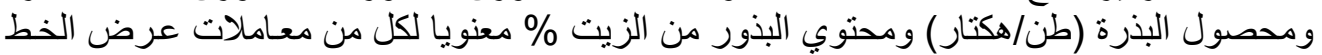

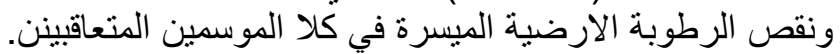

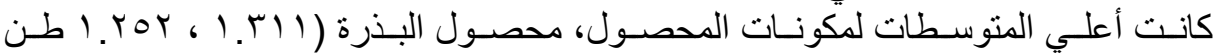

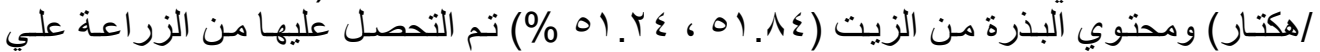

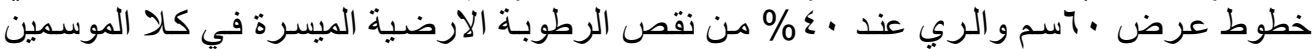

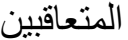

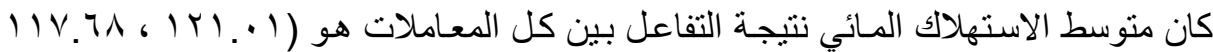

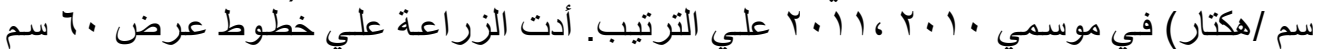

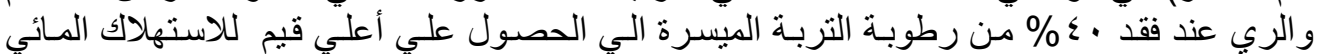

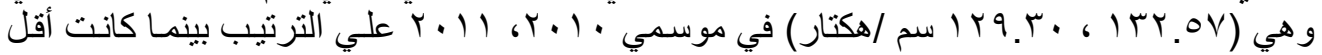

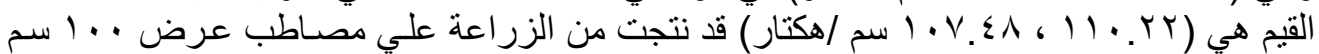

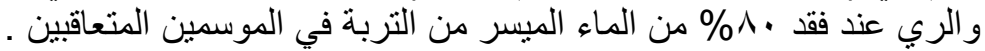

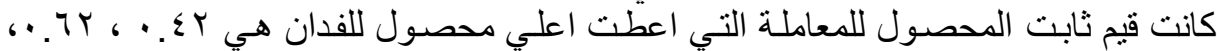

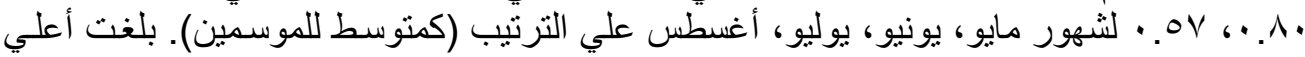

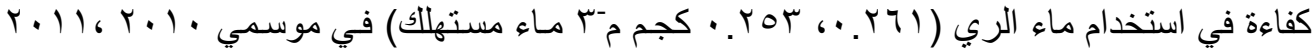

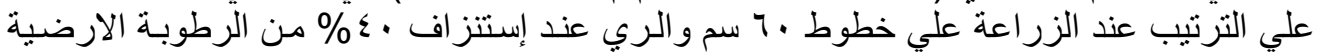
الميسرة من البخر التراكمي لوعاء البعاء البخر القياسي.

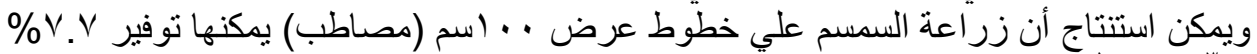

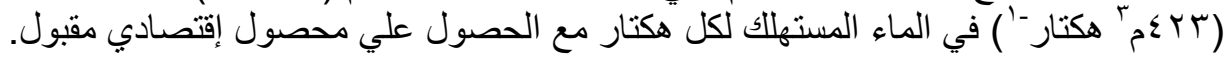

Fayoum J. Agric. Res. \& Dev., Vol. 26, No.2, July, 2012 